\title{
Orbital abscess secondary to acute dacryocystitis: case report
}

\author{
Abscesso orbitário secundário à dacriocistite aguda: relato de caso
}

\author{
Marcia Clivati Martins ${ }^{1}$ \\ José Reinaldo da Silva Ricardo ${ }^{2}$ \\ Patrícia Mitiko Santello Akaishi ${ }^{3}$ \\ Antonio Augusto Velasco eCruz ${ }^{4}$
}

\begin{tabular}{|l|}
\hline ABSTRACT \\
\hline Acute dacryocystitis usually induces preseptal infection. In rare instances \\
the infection that is confined to the lacrimal sac can extend to the orbital \\
contents resulting in orbital cellulitis. We present a case of intraconal \\
abscess secondary to acute dacryocystitis and review the literature of \\
orbital cellulitis resulting from acute lacrimal sac infection.
\end{tabular}

Keywords: Lacrimal apparatus diseases; Dacryocystitis/complications; Orbital diseases/ etiology; Cellulitis; Abscess; Bacterial infections; Case reports [Publication type]

\section{INTRODUCTION}

The immediate consequence of nasolacrimal duct obstruction is epiphora. In chronic cases conjunctivitis and mucoid discharge ensue. Acute dacryocystitis may develop when significant bacterial growth occurs in the stagnant fluid of the lacrimal sac. The main complication of acute dacryocystitis is lacrimal sac abscess that often leads to draining fistulas to the skin. The infection can also spread to the lower eyelid tissues, becoming a preseptal cellulitis. Orbital extension rarely can occur ${ }^{(1-10)}$ and may result in intraconal abscess formation ${ }^{(2-5,8)}$. We present a case of intraconal abscess secondary to acute dacryocystitis and review the literature of orbital cellulitis caused by acute dacryocystitis.

Trabalho realizado no Departamento de Oftalmologia, Otorrinolaringologia e Cirurgia de Cabeça e Pescoço da Faculdade de Medicina de Ribeirão Preto - Universidade de São Paulo.

${ }^{1}$ Médica Residente do Hospital das Clínicas da Universidade de São Paulo - USP - Ribeirão Preto (SP) - Brasil. ${ }^{2}$ Médico Residente do Hospital das Clínicas da USP Ribeirão Preto (SP) - Brasil.

Médica contratada do Setor de Oculoplástica. Hospital das Clínicas USP - Ribeirão Preto (SP) - Brasil.

${ }^{4}$ Professor Titular e Chefe do Setor de Oculoplástica do Hospital das Clínicas da USP - Ribeirão Preto (SP) Brasil.

Endereço para correspondência: Antonio Augusto Velasco e Cruz. Departamento de Oftalmologia, Otorrinolaringologia e Cirurgia de Cabeça e Pescoço, Hospital das Clínicas - Campus. Av. Bandeirantes, 3900 - Ribeirão Preto (SP) CEP 14049-900

E-mail: aavecruz@fmrp.usp.br

Recebido para publicação em 22.07.2007 Aprovação em 18.11.2007

Nota Editorial: Depois de concluída a análise do artigo sob sigilo editorial e com a anuência da Dra. Joelice dos Santos Araújo sobre a divulgação de seu nome como revisora, agradecemos sua participação neste processo.

\section{CASE REPORT}

CASE REPORT

A 39-year-old, otherwise healthy woman presented to the emergency department of the "Hospital Clinicas Faculdade Medicina Ribeirão Preto Universidade de São Paulo - HCFMRP-USP" with fever and a history of yellowish discharge, eyelid swelling, pain, redness, and reduced vision in the left eye. She reported epiphora in the last six months and denied any sinus disease, periocular trauma or prior infections. She had been using $500 \mathrm{mg}$ oral cephalexin every 6 hours in the last days. Her visual acuity was 20/20 in the right eye and 20/100 in the left. The pupils were equal, with normal reflexes. She presented with a clear abscess on the lower eyelid, with pus drainage occurring upon external pressure. The left eye was proptotic with an important degree of chemosis and extraocular motility limitation (Figure 1). The patient was admitted to the hospital and intravenous therapy was started with $1 \mathrm{~g}$ ceftriaxone every 12 hours. Her leukocyte count was $15.6 \times 10^{9} / \mathrm{L}$, with $84 \%$ segmented neutrophils and $16 \%$ lymphocytes. A computed tomography (CT) scan of the orbits showed left proptosis, severe soft tissue edema and intraconal abscesses, with no signs of rhinosinusitis (Figure 2). The patient was submitted to orbital drainage under general 
anesthesia. The orbit was approached through a subciliary incision. The abscess was located and drained, releasing a large amount of pus. After drainage of the abscess, irrigation of the lacrimal sac through the lower canaliculus clearly demonstrated that the sac was ruptured. The skin was closed and a small Penrose drain was left in the wound. On the third postoperative day the patient was afebrile, with a marked decrease in eyelid swelling and improved ocular motility of the left eye. Culture of the tissues grew strictly anaerobic bacteria (Peptostreptococcus prevotii and Prevotella melaninogenica). After resolution of the infection her final visual acuity was 20/20 in both eyes and an external dacryocystorhinostomy (DCR) was performed.

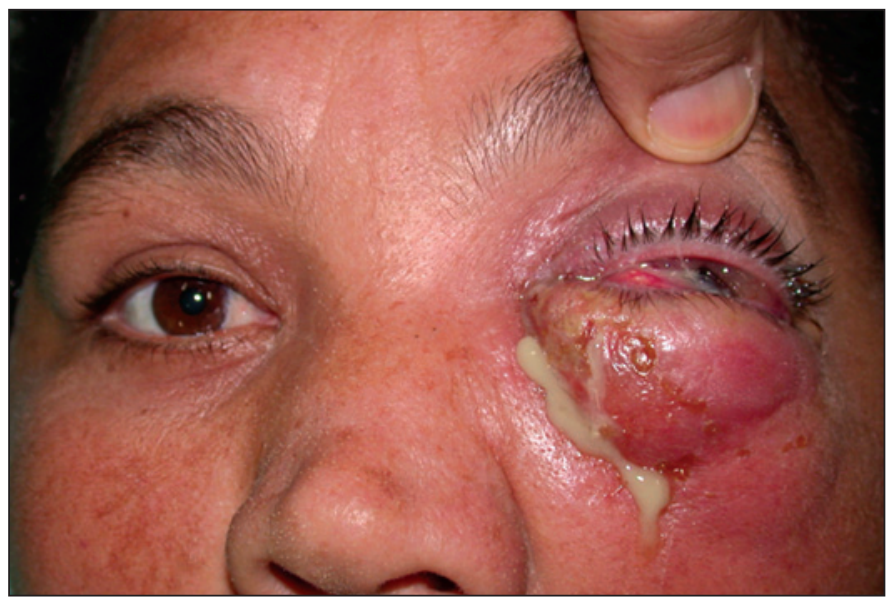

Figure 1 - Clinical aspect at presentation. Note non axial proptosis and chemosis.

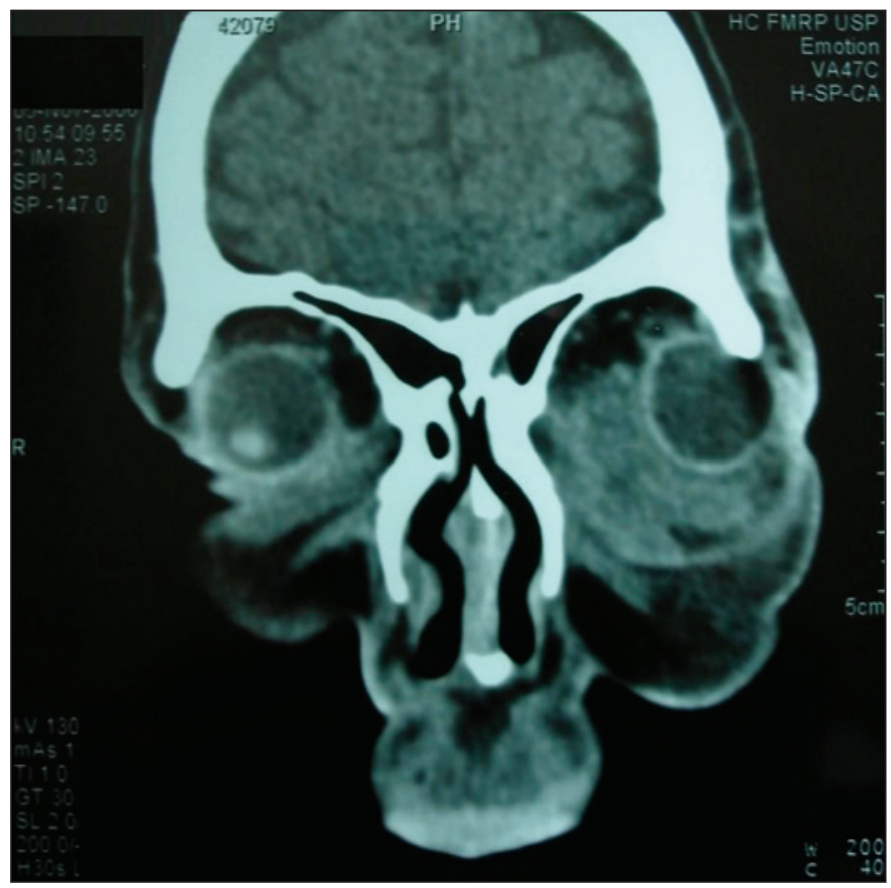

Figure 2 - Coronal computed tomographic scan showing a left lacrima sac abscess adjacent to an extra- and intraconal orbital abscess pushing globe laterally and outward

\section{DISCUSSION}

Dacryocystitis is a rare cause of orbital infection. A literature search using the Medline data base showed only 10 reports of orbital cellulitis (13 cases) caused by acute dacryocystitis (Table 1). For 7 patients $(53.8 \%)$ the infection reached the intraconal space forming an abscess. The rarity of orbital extension has been attributed to the fact that the lacrimal sac is a preseptal structure. In fact, the orbital septum inserts posteriorly at the lacrimal crest, acting as an anatomic barrier. In addition, other anatomical elements such as the lacrimal fascia, the posterior limb of the medial canthal ligament, and deep heads of the pretarsal and preseptal orbicularis muscles (Horner muscle) also act as a barrier to posterior extension.

Once the infection ruptures the lacrimal sac the posterior barriers may be overcome by the infection, leading to orbital cellulitis. Because of the anterior and inferior location of the lacrimal sac a channel of communication can be formed between the medial and inferior rectus muscles directly to the intraconal space, leading to an intraconal abscess ${ }^{(2-3,5)}$.

Table 1 shows that the microorganisms found in dacryocystitis-induced orbital cellulitis do not differ from the germs found in uncomplicated dacryocystitis. In most cases $(53.8 \%)$ single isolates of gram-positive bacteria are found. There were only four polymicrobial infections $(30.8 \%)$, with strictly anaerobic bacteria in two of them.

Orbital abscess formation can occur even in patients using oral antibiotics and can rapidly lead to visual loss ${ }^{(2)}$. Intravenous antibiotic therapy is necessary in all cases of orbital cellulitis; because of its bacteriology we consider the use of intravenous oxacillin, 2 g every 6 hours, and ceftriaxone, $2 \mathrm{~g}$ every 12 hours, as the first empirical option.

Although intravenous antibiotic therapy is necessary, surgical drainage of the abscess is mandatory for the resolution of the acute orbital picture. DCR can be delayed until complete resolution of the acute infectious disease.

The present report demonstrates that acute dacryocystitis can be added to the list of causes of orbital abscess and may be a cause of visual loss. In view of this type of complication, we conclude that patients with acute infection of the lacrimal sac should be carefully monitored.

\section{RESUMO}

A dacriocistite aguda comumente evolui para infecção préseptal. Raramente a infecção localizada no saco lacrimal pode estender-se ao conteúdo orbitário resultando em celulite orbitária. Apresentamos um caso de abscesso orbitário intraconal secundário à dacriocistite aguda e uma revisão de literatura de celulite orbitária causada por infecção aguda do saco lacrimal.

Descritores: Doenças do aparelho lacrimal; Dacriocistite/complicações; Doenças orbitárias/etiologia; Celulite; Abscesso; Infecções bacterianas; Relatos de casos [Tipo de publicação] 


\begin{tabular}{|c|c|c|c|c|c|c|c|}
\hline Author, year & Age & Sex & Imaging & $\begin{array}{l}\text { Orbital infection } \\
\text { category }\end{array}$ & Management & Culture & FVA \\
\hline Schmitt et al., $2005^{(1)}$ & $71 \mathrm{y}$ & M & CT, MRI & Diffuse cellulitis & IV Antib, DCR & Staph. aureus & $20 / 25$ \\
\hline \multirow[t]{4}{*}{ Kikkawa et al., $2002^{(2)}$} & $38 \mathrm{y}$ & $F$ & CT & Extraconal abscess & IV Antib, AD, DCR & Staph. aureus & NLP \\
\hline & $64 \mathrm{y}$ & $\mathrm{F}$ & CT & Intraconal abscess & $\begin{array}{l}\text { IV Antib, AD, DCR } \\
\text { with silicone stents }\end{array}$ & $\begin{array}{l}\text { Nonenterococcal group D } \\
\text { strep. Strep. viridans, } \\
\text { Strep. intermedius }\end{array}$ & NLP \\
\hline & 62 y & $\mathrm{F}$ & CT & Intraconal abscess & $\begin{array}{l}\text { IV Antib, AD, DCR } \\
\text { with silicone stents }\end{array}$ & $\begin{array}{l}\text { Strep. viridans, Strep. } \\
\text { intermedius, Veillonella parvula }\end{array}$ & $20 / 25$ \\
\hline & $51 \mathrm{y}$ & M & CT & Intraconal abscess & $\begin{array}{l}\text { IV Antib, Endo-DCR } \\
\text { with silicone stents }\end{array}$ & Negative & $20 / 20$ \\
\hline Ataulla et al., $2002^{(3)}$ & $60 y$ & $\mathrm{~F}$ & CT & Intraconal abscess & $\begin{array}{l}\text { IV Antib, } A D, D C R \\
\text { recommended }\end{array}$ & Strep. spp & $20 / 60$ \\
\hline Ntountas et al., $1997^{(4)}$ & $38 \mathrm{y}$ & M & $\begin{array}{l}\text { CT, } \\
\text { MRI, } \\
\text { US }\end{array}$ & Intraconal abscess & IV Antib, AD, DCR & $\begin{array}{c}\text { Strep. anginosus, } \\
\text { Peptostreptococcus, } \\
\text { Anaerobic gram-negative } \\
\text { rods }\end{array}$ & $20 / 20$ \\
\hline Mauriello et al., $1996^{(5)}$ & $84 \mathrm{y}$ & $\mathrm{F}$ & CT & Intraconal abscess & $\begin{array}{l}\text { IV Antib, AD, } \\
\text { Dacryocystectomy }\end{array}$ & Staph. aureus & NS \\
\hline Warrak et al., $1996^{(6)}$ & $62 \mathrm{y}$ & M & CT & Subperiosteal abscess & IV Antib, AD, DCR & Morganella morganii & NS \\
\hline Weiss et al., $1993^{(7)}$ & $15 d$ & $\mathrm{~F}$ & CT & Intraconal abscess & IV Antib, AD & Staph. aureus & NS \\
\hline Molgat et al., $1993^{(8)}$ & $40 y$ & M & CT & Extraconal abscess & IV Antib, AD, DCR & Strep. viridans & $20 / 20$ \\
\hline Allen et al., $1985^{(9)}$ & $57 \mathrm{y}$ & $\mathrm{F}$ & $\begin{array}{l}\text { CT, } \\
\text { US }\end{array}$ & Diffuse cellulitis & IV Antib & $\begin{array}{l}\text { Eikenella corrodens, } \\
\text { Enterobacter aerogenes }\end{array}$ & $20 / 20$ \\
\hline Ahrens-Pallumbo et al., $1982^{(10)}$ & $60 y$ & $\mathrm{~F}$ & CT & Extraconal abscess & IV Antib, DCR & Staph. epidermidis & $20 / 20$ \\
\hline Present report & $39 \mathrm{y}$ & $\mathrm{F}$ & CT & Intraconal abscess & IV Antib, AD, DCR later & $\begin{array}{l}\text { Peptostreptococcus } \\
\text { prevotii, Prevotella } \\
\text { melaninogenica }\end{array}$ & $20 / 20$ \\
\hline
\end{tabular}

\section{REFERENCES}

1. Schmitt NJ, Beatty RL, Kennerdell JS. Superior ophthalmic vein thrombosis in a patient with dacryocystitis-induced orbital cellulitis. Ophthal Plast Reconstr Surg. 2005;21(5):387-9.

2. Kikkawa DO, Heinz GW, Martin RT, Nunery WN, Eiseman AS. Orbital cellulitis and abscess secondary to dacryocystitis. Arch Ophthalmol. 2002;120(8):1096-9.

3. Ataullah S, Sloan B. Acute dacryocystitis presenting as an orbital abscess. Clin Experiment Ophthalmol. 2002;30(1):44-6.

4. Ntountas I, Morschbacher R, Pratt D, Patel BC, Anderson RL, McCann JD. An orbital abscess secondary to acute dacryocystitis. Ophthalmic Surg Lasers. 1997;28(9):758-61
5. Mauriello JA, Wasserman BA. Acute dacryocystitis: an unusual cause of lifethreatening orbital abscess with frozen globe. Ophthal Plast Reconstr Surg. 1996;12(4):294-5.

6. Warrak E, Khoury P. Orbital abscess secondary to acute dacryocystitis. Can J Ophthalmol. 1996;31(4):201-2.

7. Weiss GH, Leib ML. Congenital dacryocystitis and retrobulbar abscess. J Pediatr Ophthalmol Strabismus. 1993;30(4):271-2.

8. Molgat YM, Hurwitz JJ. Orbital abscess due to acute dacryocystitis. Can J Ophthalmol. 1993;28(4):181-3.

9. Allen MV, Cohen KL, Grimson BS. Orbital cellulitis secondary to dacryocystitis following blepharoplasty. Ann Ophthalmol. 1985;17(8):498-9.

10. Ahrens-Palumbo MJ, Ballen PH. Primary dacryocystitis causing orbital cellulitis. Ann Ophthalmol. 1982;14(6):600-1. 